\title{
Typical ECG findings in an unconscious patient
}

\author{
R. Joustra ${ }^{1,2} \cdot$ F. N. Polderman ${ }^{3}$ J. L. Smeets ${ }^{2}$ M. C. Daniëls ${ }^{1}$ M. Boulaksil ${ }^{1,2}$
}

Published online: 26 October 2016

(C) The Author(s) 2016. This article is available at SpringerLink with Open Access.

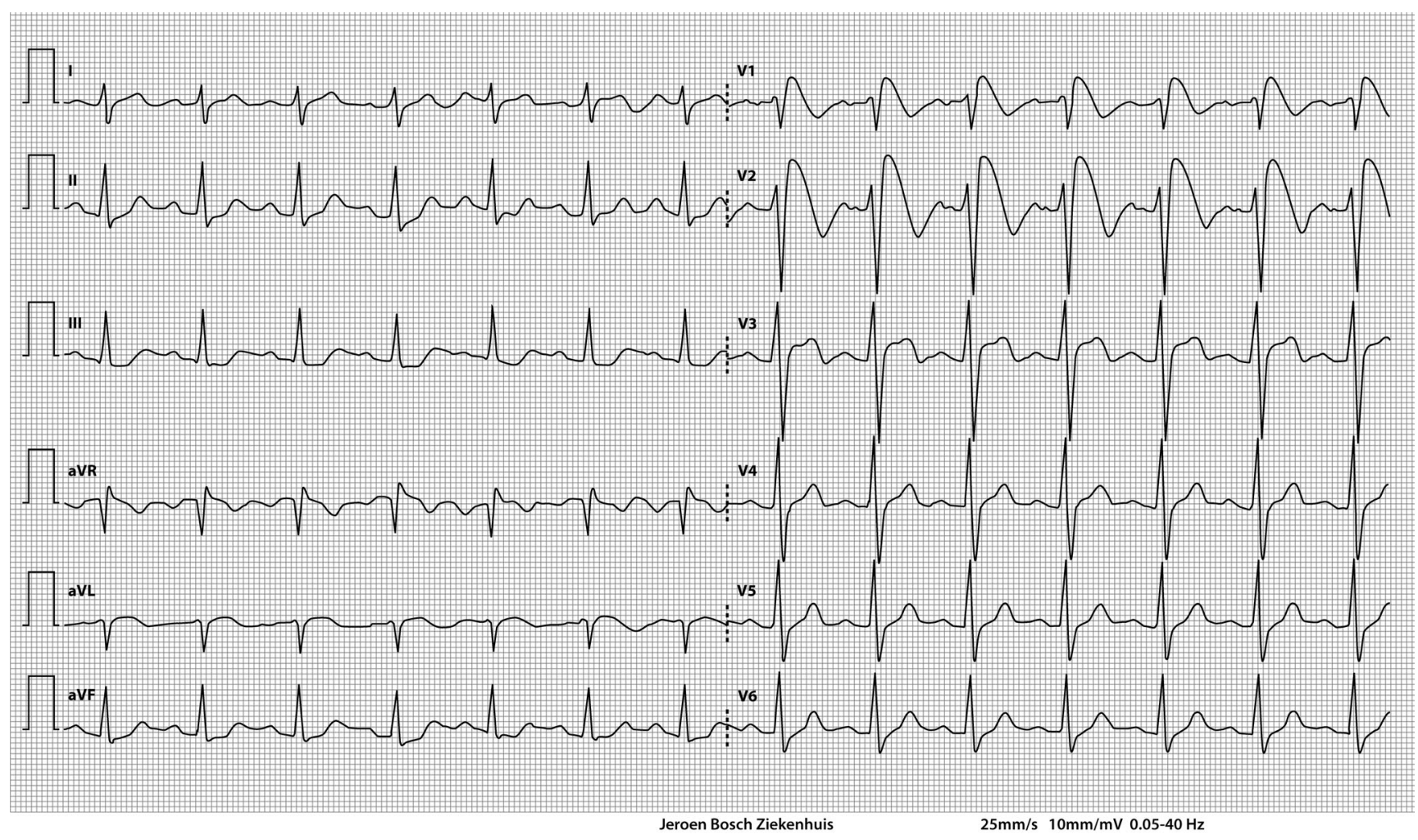

Fig. 1 ECG on admission

M. Boulaksil

m.boulaksil@gmail.com

1 Department of Cardiology, Jeroen Bosch Hospital, 's-Hertogenbosch, The Netherlands

2 Department of Cardiology, Radboud University Medical Center, Nijmegen, The Netherlands

3 Department of Intensive Care Medicine, Jeroen Bosch Hospital, 's-Hertogenbosch, The Netherlands

\section{Answer}

Notably, the ECG on admission shows a Brugada-like electrocardiographic pattern (with right bundle branch block and typical ST-segment elevations in leads V1-V3 with a terminal negative $\mathrm{T}$ wave). This Brugada-like pattern is called coved type or type 1 (Fig. 1).

In individuals with a normal baseline ECG, this pattern can be provoked by controlled infusion of sodium channel blocking agents for the diagnosis of Brugada syndrome 


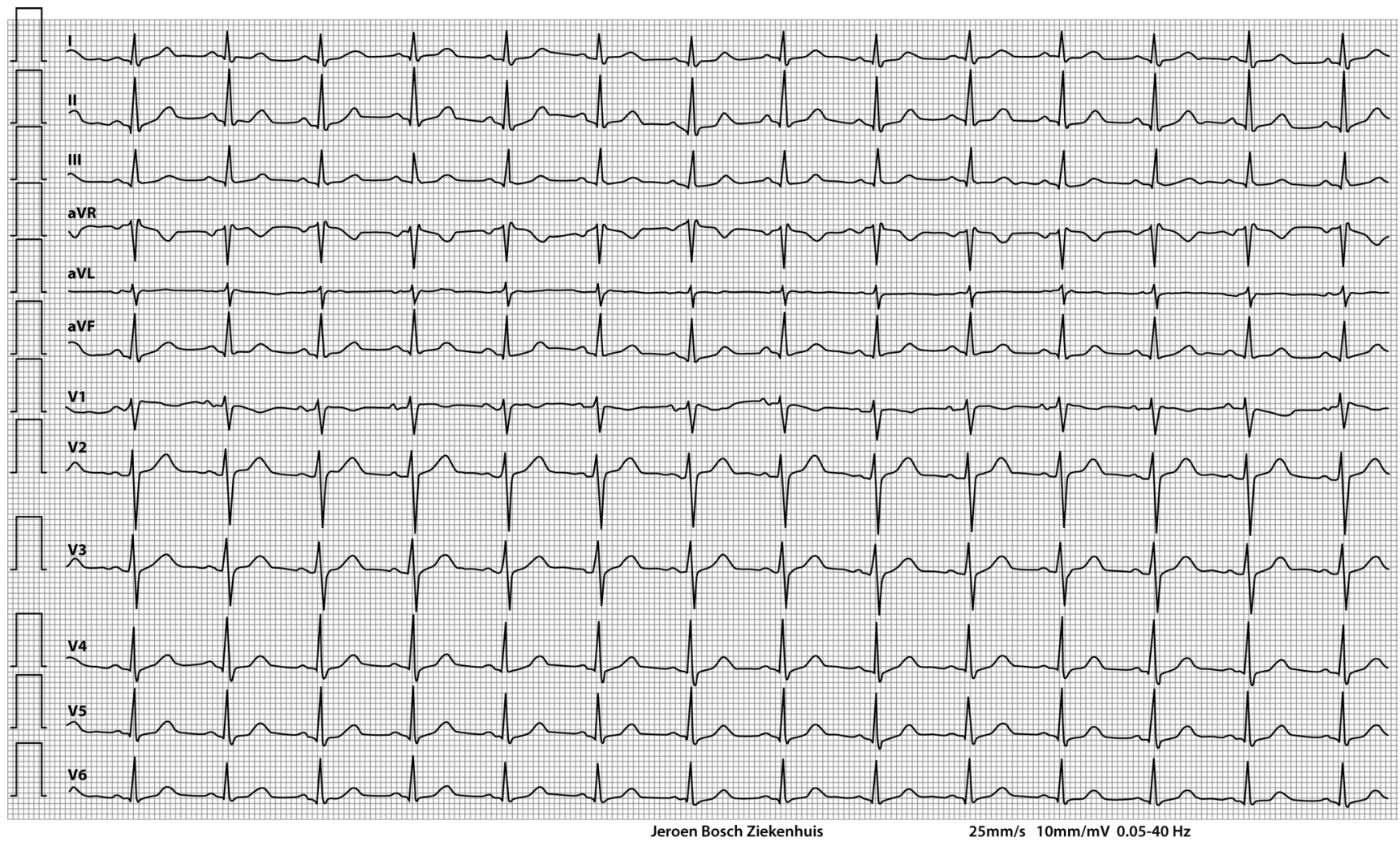

Fig. 2 Follow-up ECG after discharge from the intensive care unit

[1]. However, intoxication with a sodium channel blocking agent may give rise to a transient Brugada-like pattern without an underlying Brugada syndrome.

In patients with a psychiatric history, one should consider involvement of a tricyclic antidepressant (TCA), since TCAs are known to result in sodium channel blockade [2]. Our patient turned out to be using nortriptyline, a TCA, amongst other non-tricyclic antidepressants. Therefore, the suspicion of an intoxication with this drug was raised [3]. Indeed, blood tests showed toxic levels of nortriptyline $(507 \mu \mathrm{g} / \mathrm{l}$ (therapeutic levels: $50-150 \mu \mathrm{g} / \mathrm{l}$; toxic levels: $>500 \mu \mathrm{g} / \mathrm{l})$, E-10-OH-nortriptyline $386 \mu \mathrm{g} / \mathrm{l}$ ).

She was admitted to the intensive care unit and treatment with activated charcoal was started to reduce enteral absorption. Furthermore, she was alkalinised with sodium bicarbonate infusion in order to increase binding of nortriptyline to serum proteins. On follow-up, the ECG abnormalities eventually dissolved (Fig. 2).

\section{Conclusion}

Type 1 Brugada-like ECG pattern provoked by TCA intoxication.
Conflict of interest R. Joustra, F.N. Polderman, J.L. Smeets, M.C. Daniëls and M. Boulaksil declare that they have no competing interest.

Open Access This article is distributed under the terms of the Creative Commons Attribution 4.0 International License (http:// creativecommons.org/licenses/by/4.0/), which permits unrestricted use, distribution, and reproduction in any medium, provided you give appropriate credit to the original author(s) and the source, provide a link to the Creative Commons license, and indicate if changes were made.

\section{References}

1. Antzelevitch C, Brugada P, Borggrefe M, et al. Brugada syndrome: report of the second consensus conference: endorsed by the Heart Rhythm Society and the European Heart Rhythm Association. Circulation. 2005;111:659-70.

2. Meert A, Vermeersch N, Beckers R, Hoste W, Brugada P, Hubloue I. Brugada-like ECG pattern induced by tricyclic antidepressants. Eur J Emerg Med. 2010;17:325-7.

3. Tada H, Sticherling C, Oral H, Morady F. Brugada syndrome mimicked by tricyclic antidepressant overdose. J Cardiovasc Electrophysiol. 2001;12:275. 